\title{
Multiple Model Mimicry and Feeding Behavior of the Spider Web-Inhabiting Damsel Bug, Arachnocoris berytoides Uhler (Hemiptera: Nabidae), from Puerto Rico ${ }^{1}$
}

\author{
Javier E. Mercado ${ }^{2}$ and Jorge A. Santiago-Blay ${ }^{3}$
}

\begin{abstract}
The Neotropical genus, Arachnocoris Scott groups thirteen species of specialized spider web-inhabiting damsel bugs (Nabidae) distributed from Panama to Brazil and the West Indies. We present new information on the web behavior of A. berytoides Uhler from Puerto Rico. Three different life stages were observed on the spider webs, suggesting this species likely depends on that microhabitat for all its life history stages. In addition to the modified tarsi described by Myers, we describe mimetic adaptations that may help it live a life in close association with its predacious host. Species in this genus are facultative kleptoparasites that are highly dependent on spider webs for obtaining their food. In Puerto Rico, Arachnocoris berytoides perhaps mimics multiple models through several types of mimicry including: Aposematic, Aggressive, Batesian-Wallacean, Wicklerian-Eisnerian, and possibly Mullerian-Batesian mimicry. An observation in which a male watched as females approach a food item might represent a type of mate guarding behavior not previously described in this genus.
\end{abstract}

Key Words: Arachnophilic, Hemiptera, Nabidae, myrmecomorphy, kleptoparasitic

Several groups of insects, including the Embioptera, or web spinners (Bradoo and Joseph 1970), Hemiptera, or true bugs (examples below), Diptera, or flies (Weinmann and Disney 1997), Lepidoptera, or butterflies and moths (Nafus and Schriener 1991), and others have evolved close relationships with non-insect arthropods, including some of their most important predators, the spiders. Some spider associates have evolved noteworthy strategies that allow them to safely share or steal host prey, or even prey on their hosts. One of the largest groups of spider web-inhabiting insects can be found in the order Hemiptera, represented in the tropics by several arachophilic species in the families Miridae (Henry 1984, Murphy and Polhemus 2012), Nabidae (see below), Plokiophilidae (Popov 2008), and Reduviidae (Santiago-Blay and Maldonado Capriles 1988, Soley et al. 2011). Some of the most fascinating specializations of hemipterans occur in the subfamily Emesinae (Reduviidae) living on spider webs. Emesines, like Emesa tenerrima Dohrn and Stenolemus giraffa Wygodzinsky, mimic their spider prey models, a type of mimetism called Batesian-Wallacian mimicry. These mimics not only simulate their prey shape and leg color pattern, but also their shaking behavior (Santiago-Blay and

\footnotetext{
${ }^{1}$ Submitted on March 29, 2015. Accepted on April 6, 2015. Last revisions received on April 15, 2015.

${ }^{2}$ Corresponding author: USDA FS-Rocky Mountain Research Station, 240 West Prospect Fort Collins, Colorado 80526 USA. E-mail: jmercado01@fs.fed.us

${ }^{3}$ Department of Paleobiology, National Museum of Natural History, Smithsonian Institution, Washington, District of Columbia 20560 USA. E-mail: $\underline{\text { blayj@ si.edu }}$
} 
Maldonado Capriles 1988; Soley et al. 2011; JEM, unpublished observations). The symbiosis between spider web-inhabiting Arachnocoris and their hosts is considered a commensalism (Henry 1984; Lopez 1990; Sewlal and Starr 2008, 2009), since these are thought to benefit from their close association with their spider hosts, without harming them. We consider species of Arachnocoris kleptoparasitic, a symbiosis in which the insect inquiline steals food from its host, potentially antagonizing their fitness. We present some evidence supporting this type of relationship.

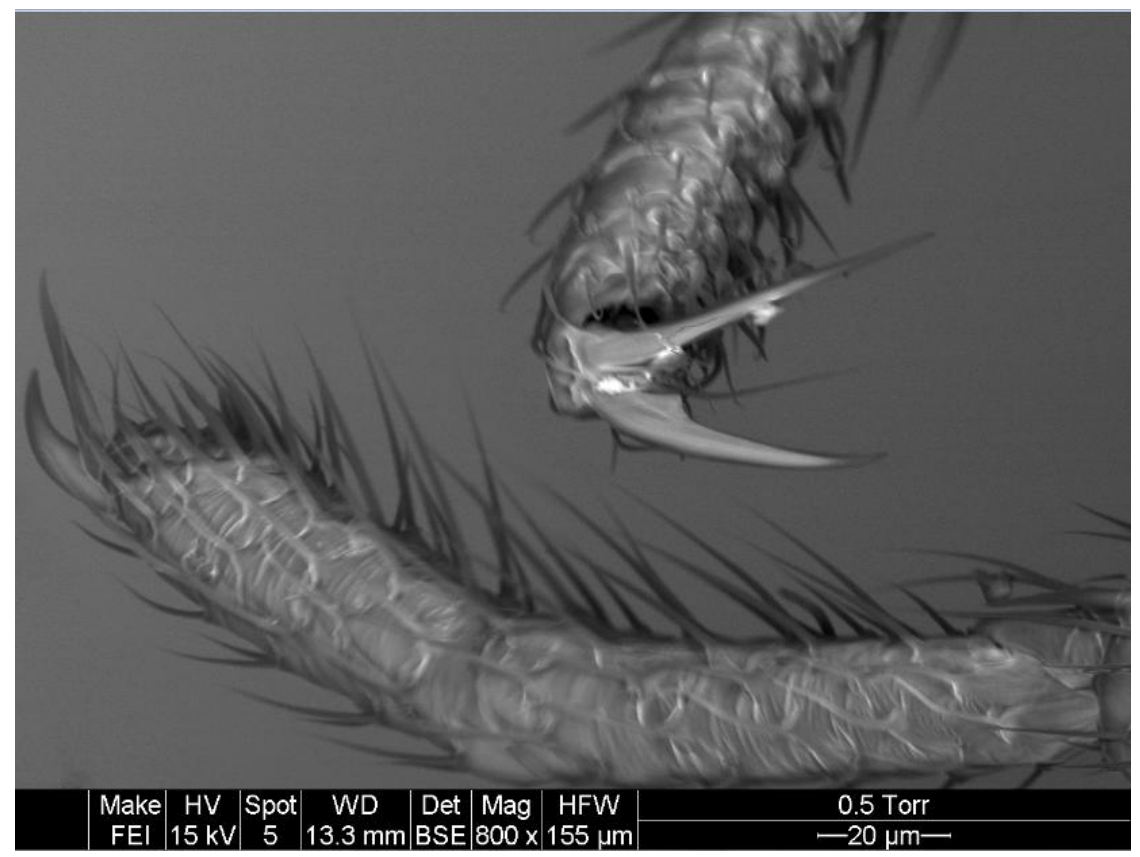

Figure 1. Scanning electron micrograph of the mesotarsi of a female Arachnocoris berytoides. Image by J. A. Santiago-Blay; lightly touched by E. Leavell (The ITSupport Center).

Not surprisingly, our knowledge of the natural history of species of Arachnocoris has often come from arachnologists. In 1881, the British entomologist John Scott cleverly assigned the name Arachnocoris Scott to a genus of small nabids found living on spider webs by the arachnologist-at-heart Reverend Octavius Pickard-Cambridge. Web-living Arachnocoris have smooth tarsal claws (Figure 1) that bend towards their tarsi allowing these to walk upside-down on the webs of their hosts without entangling and becoming prey (Lopez-Moncet 1990, 1997). 
Thirteen species comprise this genus (Coscarón and Volpi 2013), with most species found in continental Neotropics, particularly South America, from Brazil to Venezuela (eight species) and Central America, from Costa Rica and Panama (three species). Their close association with spiders has not prevented their movement to islands in the West Indies where A. trinitatis Bergroth is found on Trinidad and the strikingly patterned species Arachnocoris berytoides Uhler occurs from Grenada to Puerto Rico.

Given the difficulty of finding Arachnocoris, a fact sustained by the small representation of most species in museum collections, observations of their behavior are limited. Species of Arachnocoris have been frequently described living under horizontal webs of spiders in the families Pholcidae Koch (Bergroth 1914; Kerzhner 1990; Lopez-Moncet 1990, 1997). But also, these have been found infrequently in non-sticky web strands of cobweb spiders (Theridiidae) (Myers 1925), as well as in the orb-weaver spiders (Araneidae) (Myers 1925). Different life stages of these predatory bugs have been documented to co-exist with their living spider hosts in which webs these feed on entangled prey (Myers 1925, Sewlal and Stark 2008). Mimicry is apparent in both immature and adult stages, resembling both insect and non-insect arthropod taxa. However, with the exception of the myrmecoid larvae (Myers 1925, Lopez 1990) other specific types of mimicry have been only rarely suggested. Like the immature of other hemipteran families, it has been proposed that the larvae of Arachnocoris resemble ants (Myers 1925, McIver and Stonedahl 1993); however, adults can resemble other arthropods. For example, the white spots on the abdomen of adult's bugs have previously been considered to resemble those found in kleptoparasitic spiders in the genus Argyrodes Simon (Myers 1925).

The first author noticed the tiny adults of Arachnocoris while searching for pholcid spiders in El Yunque National Forest on eastern Puerto Rico, just as the second author did with emesine reduviids years earlier in another forest (Santiago-Blay and Maldonado-Capriles 1988). The biological information and discussion in this paper aims to increase the knowledge and stimulate further research about this fascinating group by providing new information of its life on the web, its feeding, and its mimicry. Specifically, we describe its resemblance to immatures of its spider host, a host's commensal spider, and to a vespid wasp.

\section{Locality of Observations}

Observations of A. berytoides were made in El Yunque National Forest located in northeastern Puerto Rico. This rain forest sustains a lush carpet of mosses, ferns, and vines that, among other small plants, hang from the banks of streams and other steep landscape features providing a niche to small arthropods, such as spiders, seeking protection from the copious and frequent rain. Arachnocoris were observed on several occasions along banks that were sheltered by vegetation on El Yunque Trail in the Baño de Oro Natural Area at an elevation of approximately $800 \mathrm{~m}$ and once on a web made under foliage at 
El Portal at an elevation of $160 \mathrm{~m}$ above sea level. Species in this genus appear to have small geographical distributions, perhaps due to their highly specialized microhabitats. In the circum-Caribbean region, hosts are primarily spiders in the family Pholcidae including the genera Coryssocnemis Simon, Mesabolivar González-Sponga, and Modisimus Simon, this last genus represents one with a considerable strong island species-level endemism in the West Indies (e.g. Hispaniola, see Huber et al. 2010). The color patterns of the adult antenna and femora vary between species and have been used to distinguish some species of Arachnocoris. We suspect that these traits may be of ecological importance in this group.

\section{Imaging}

Live photography was taken with a Canon DSLR (8MP) fitted to a $100 \mathrm{~mm}$ macro lens and lens extenders. Scanning electron microscopy was performed on a Philips XL-30 Environmental Scanning Electron Microscope (ESEM) at the Imaging Laboratory of the National Museum of Natural History (Washington, DC).

\section{Biological Observations and Discussion}

From six pholcid spider species found in the collection locality, only two made large horizontal webs, harboring A. berytoides. The four spiders not hosting Arachnocoris included three predominantly ground inhabiting species and a fourth that builds small webs on the face of green leaves, all in the genus Modisimus. Observations of Arachnocoris were made on ten different spider webs. Nine observations were made in the Baño de Oro area, where the spider host was an undescribed species of Modisimus (B. Huber personal communication to author JEM). The tenth observation was made at a secondary forest at El Portal visitor center where it was found on the empty web of $M$. signatus Banks. The information herein presented is limited to the presence or absence of spider hosts and to feeding behavior. The host spider was visible only in six of the ten observed webs containing Arachnocoris. Different developmental stages of $A$. berytoides were observed sharing a web during the first week of November 2007. On one occasion, three specimens were an adult male and two late instar females. On another occasion an early (possibly first instar) bright red larva (Figure 2) was observed among the adults on a web, suggesting that all developmental stages of the insect live in this habitat. Other adults were observed in March and April of 2008.

Feeding observations were made at the higher elevation site, where $A$. berytoides were seen feeding in two occasions. On a host-occupied web, an adult male watched as two pre-adult females fed on a small reddish-brown hymenopteran, the male appeared to be guarding the females (Figure 3); a behavior that could represent pre-copulatory mate guarding (Parker 1974). This behavior may allow male Arachnocoris to gain rapid access to newly molted 
adult females. On a second web in which the spider host was not observed, a pre-adult female fed on the untangled spider Baazelbub albonotatus Petrunkevitch (Figure 4). On both occasions, A. berytoides held its prey with the anterior and middle raptorial legs in which the femora are vested with two rows of ventral spines, while using the non-raptorial hind pair to hold the web, a behavior also practiced by the other arachnophilic hemipteran (suggested by Santiago-Blay and Maldonado-Capriles 1988) in Puerto Rico Emesa terrenima (Figure 5).

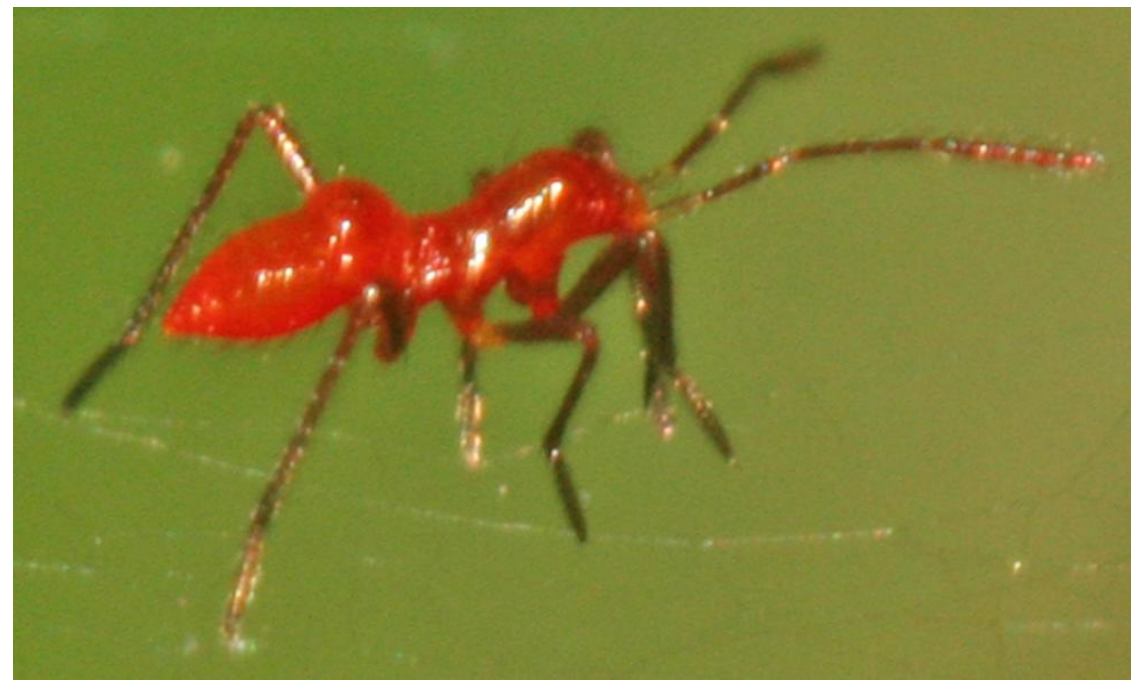

Figure 2. The bright-red myrmecoid larva of Arachnocoris berytoides, an example of aposematic mimicry. Photo by J. E. Mercado.

Similarly to our observations, Sewlal and Starr (2009) found that $A$. trinitatus did not show preference for either occupied or empty webs of their host spider, Coryssocnemis simla Huber. As nocturnal surveys were not performed in either study, it is possible that the spiders were hiding or were less obvious during the day, although leaving the web might be a strategy of host spiders under high competition pressure from kleptoparasites. Most feeding observations of Arachnocoris species have been of spider-trapped prey. Thus, Arachnocoris may benefit from host-active webs by stealing or sharing their prey suggesting a kleptoparasitic behavior requiring the presence of its host. However, our observations of $A$. berytoides feeding on an untangled spider and of A. trinitatis attacking freshly entangled prey (Sewlal and Starr 2008) suggests, that these are not obligate kleptoparasites, but that these can also hunt on the web. These nabids; however, seem to be obligatory dependent on functional webs, which in the rain forest are usually made frequently due to the dynamics of that system. This may contribute to the slightly higher, although not 
significant (Sewlal and Starr 2008), frequency of finding them on spideroccupied webs.

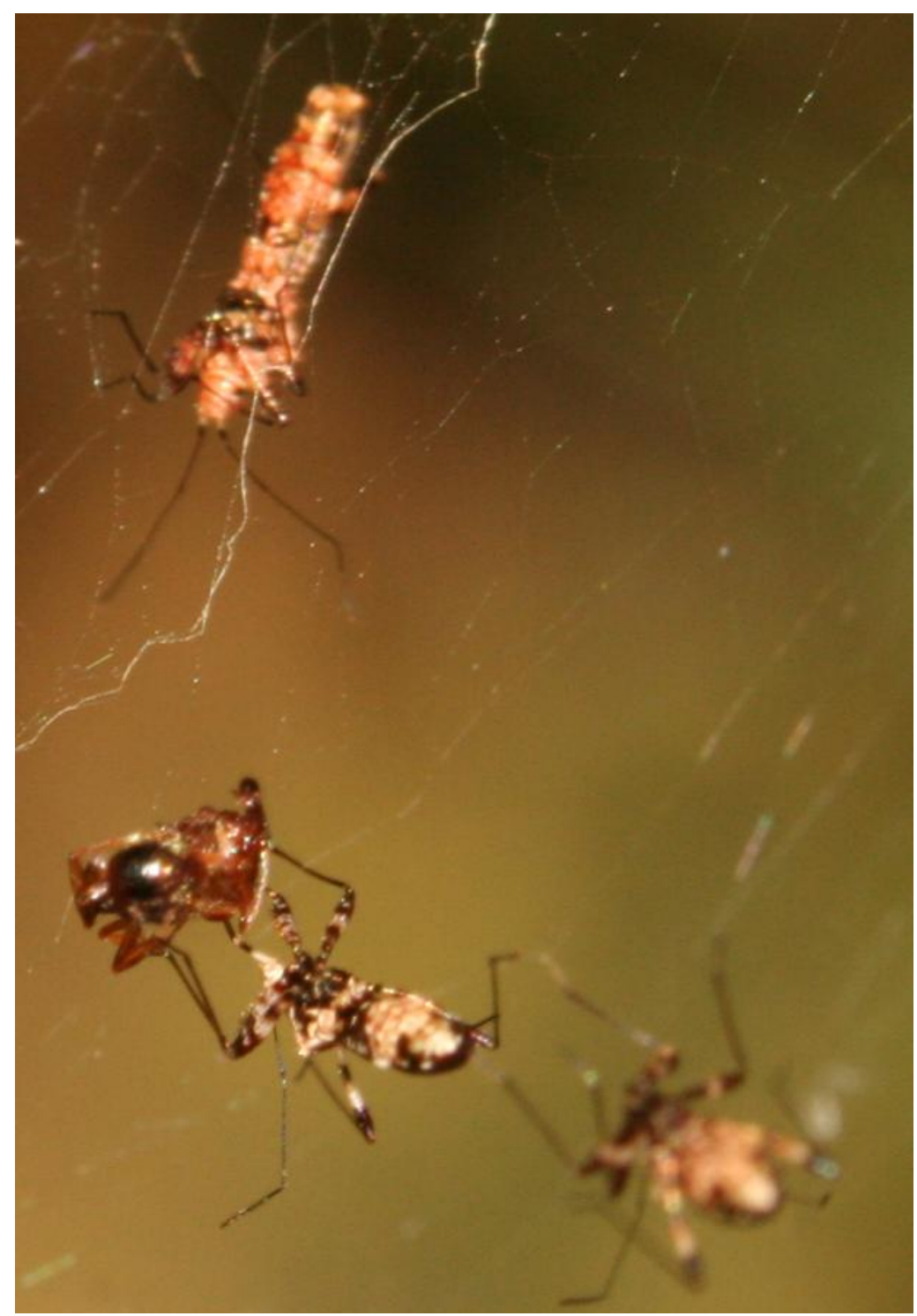

Figure 3. One late instar female Arachnocoris berytoides feeds on an entangled prey as another (lower right on the photo) approaches. Meanwhile, an adult male (top left) watches. These may represent an example of pre-copulatory guarding of a soon-tobecome mature female. Photo by J. E. Mercado. 


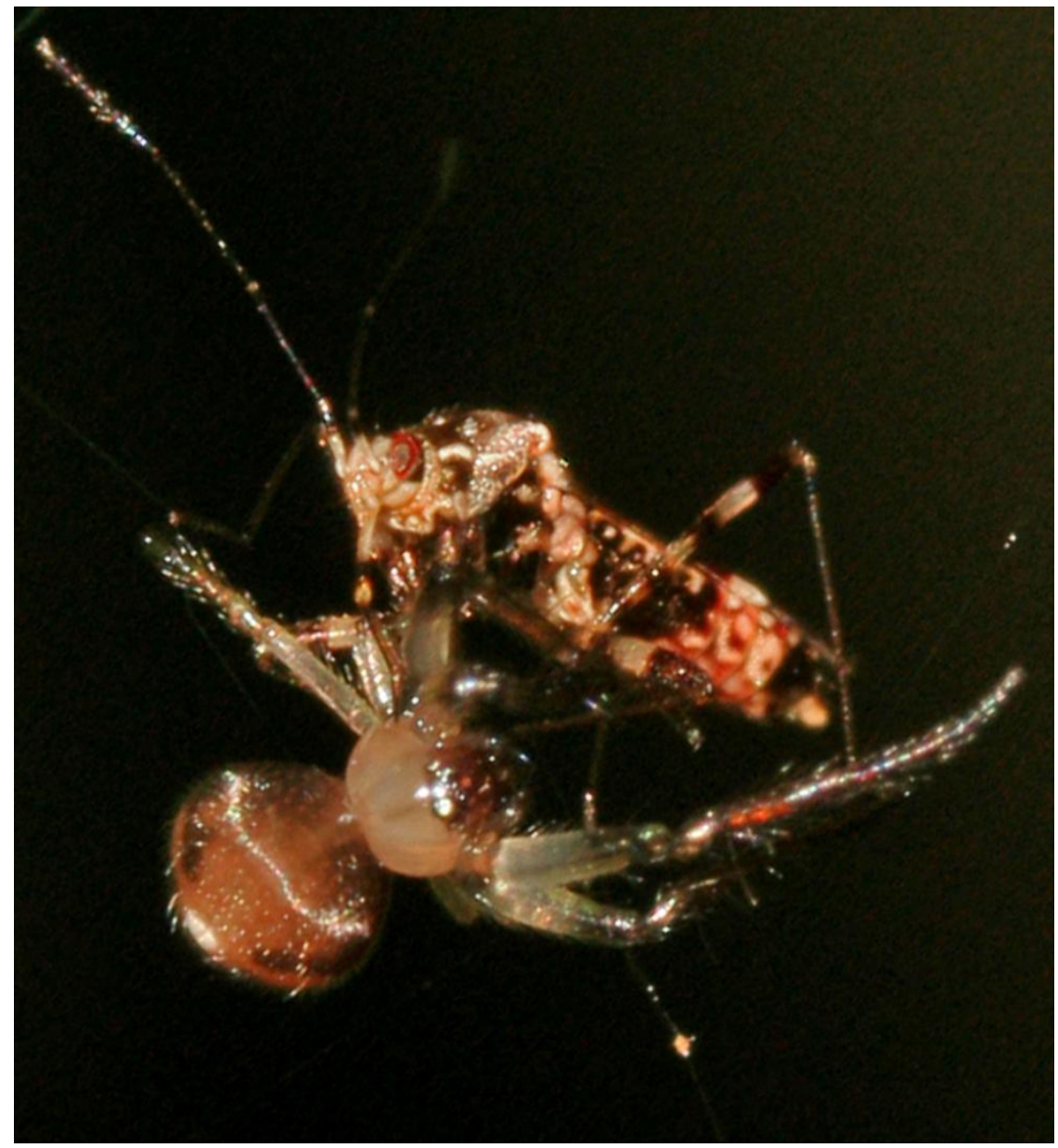

Figure 4. An adult Arachnocoris berytoides feeding on an entangled Bazelbub albonotatus Petrunkevitch spider. On this occasion the host spider was not present on the web. Photo by J. E. Mercado.

Mimicry in Arachnocoris berytoides specimens from Puerto Rico Ant mimicry or aposematism of the larva?

Early larval stages of Arachnocoris (Figure 2) are thought to resemble ants (Myers 1925). This choice of model is frequently found in other hemipteran families such as Miridae and Reduviidae (McIver and Stonedahl 1993). Having an ant as the model benefits the mimic that lives close to its model (McIver and Stonedahl 1993). This protects the mimic from experienced predators avoiding the distasteful or stinging model. Free-living ants do not visit spider webs; 
therefore, resembling an ant for species in this genus may represent a hemipteran synapomorphy without any specific known function other than Aposematism (Myers 1925). In the rain forests of Puerto Rico, hummingbirds are among the predatory visitors to webs of $A$. berytoides' hosts, where they steal spider's silk to build their nests but also take spiders and other arthropods from webs to complement their diets as well as their nestlings. The keen eyesight of these birds is especially sensitive to bright colors such as red, the color of some of their preferred flowers at high elevation in West Indian wet forests (Dalsgaard et al. 2009), making distasteful red insects easy to detect, remember, and subsequently avoid. Thus, larvae in this species may rely on aposematic coloration to warn predators of their potential foul taste.

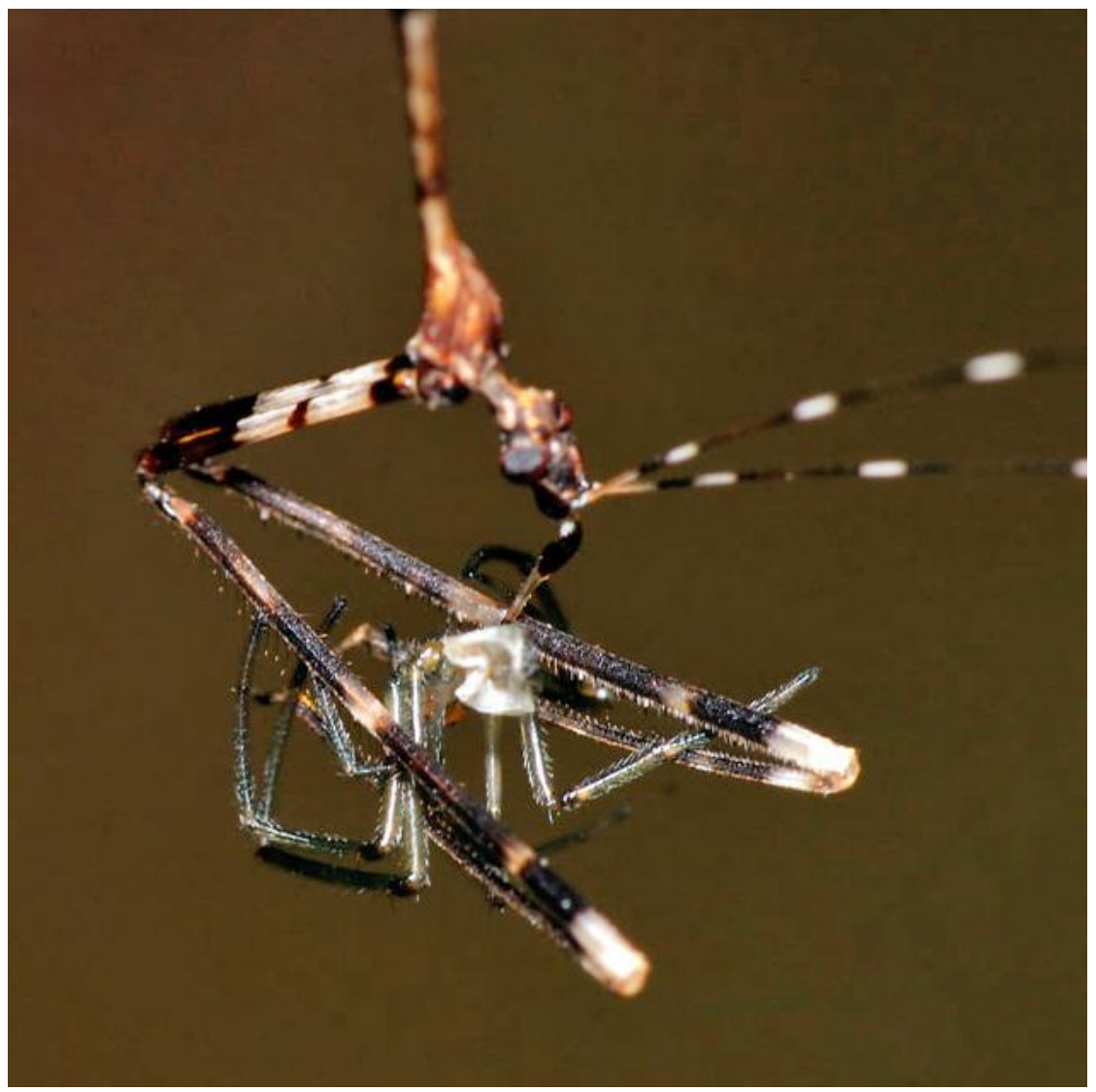

Figure 5. The arachnophilic Emesa terrenima feeds on a sub-adult Modisimus signatus. This is the first documentation of araneophagy on this species. Photo by Alfredo "Master" Colón-Archilla (Alfredocolon.zenfolio.com). 


\section{Aggressive mimicry or Batesian-Wallacian mimicry}

In our opinion, adult Arachnocoris do not resemble ants. The adult of $A$. berytoides may be simultaneously mimicking different taxa or particular life stages of its model (spider host), which becomes apparent by observing the insect from different angles. For example, when observed from approximately a $45^{\circ}$ angle, which is the spider's perception angle (Figure 6), the strongly convex shape of the prothorax conceals the rest of the body, which together with the strongly declivous head makes it resemble the globular abdomen and the low lying head of its pholcid spider host spiderlings, something that is further aided by the annulate and long legs.

A parasite that resembles its host, obtaining benefits from it, represents a type of Aggressive-mimicry (Pasteur 1982), such as kleptoparasitsm. Sewlal and Starr (2008) described how A. trinitatis kept a safe distance from the host spider suggesting that this behavior prevents the host spider from recognizing the true identity of the inquiline, except after both species were startled when both shared the same retreat. It is possible that the different leg and antenna color pattern in all species of the genus Arachnocoris has a host-specific mimicking function. Several pholcid genera tolerate the presence of early instars of their brood (observed by JEM on M. signatus). It is possible that Arachnocoris exploits this tolerance by mimicking immature spiders, and given our documentations of araneophagy, may even predate on these, in this case becoming Batesian-Wallacean mimicry (Pasteur 1982). Further research may shed light on this fascinating possibility.

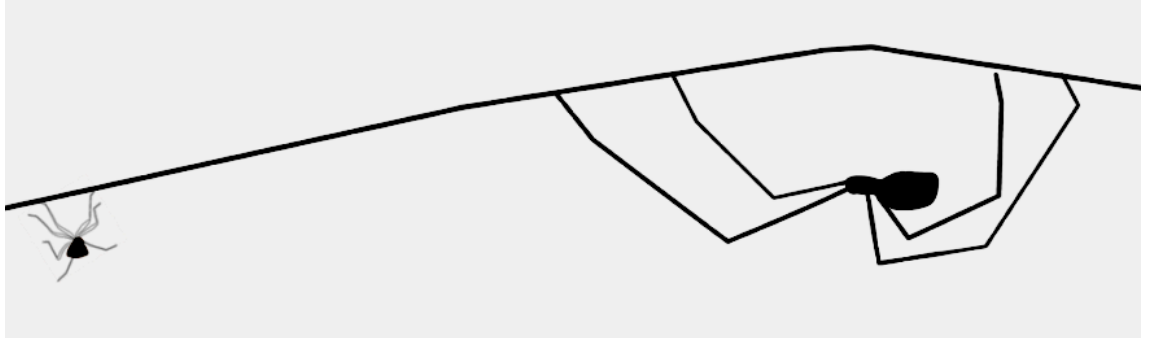

Figure 6. Modeling of spider host by an adult Arachnocoris berytoides, an example of host-parasite mimicry.

\section{Wicklerian-Eisnerian mimicry}

Species that mimic other host commensals in this way obtaining protection from the host are considered to be Wicklerian-Eisnerian mimics (Pasteur 1982). Seen from the back, the abdominal apex of male A. berytoides resembles, both in shape and color, that of the commensal spider Faiditus caudatus Taczanowski (Figure 7). This species was observed sharing the web with A. berytoides on two separate occasions. An association with these commensal spiders possibly occurs in other species of Arachnocoris. Myers (1925) suggested that the 
silvery-white abdominal spots of A. albomaculatus resembled the silver colored areas in the abdomen of the dew drop spider Argyrodes nephilae Taczanowski in Panama. A close association of Arachnocoris with the kleptoparasitic or commensal spider genera Argyrodes and Faiditus is also suggested by observations by the arachnologist Lopez-Moncet (1990, 1997), who described three new species and observed another two, while studying Argyrodes spiders in Guadeloupe, Martinique, and French Guyana. Light colored and raised abdominal spots have been described in several Arachnocoris species, these may exist to mimic kleptoparasitic spiders.

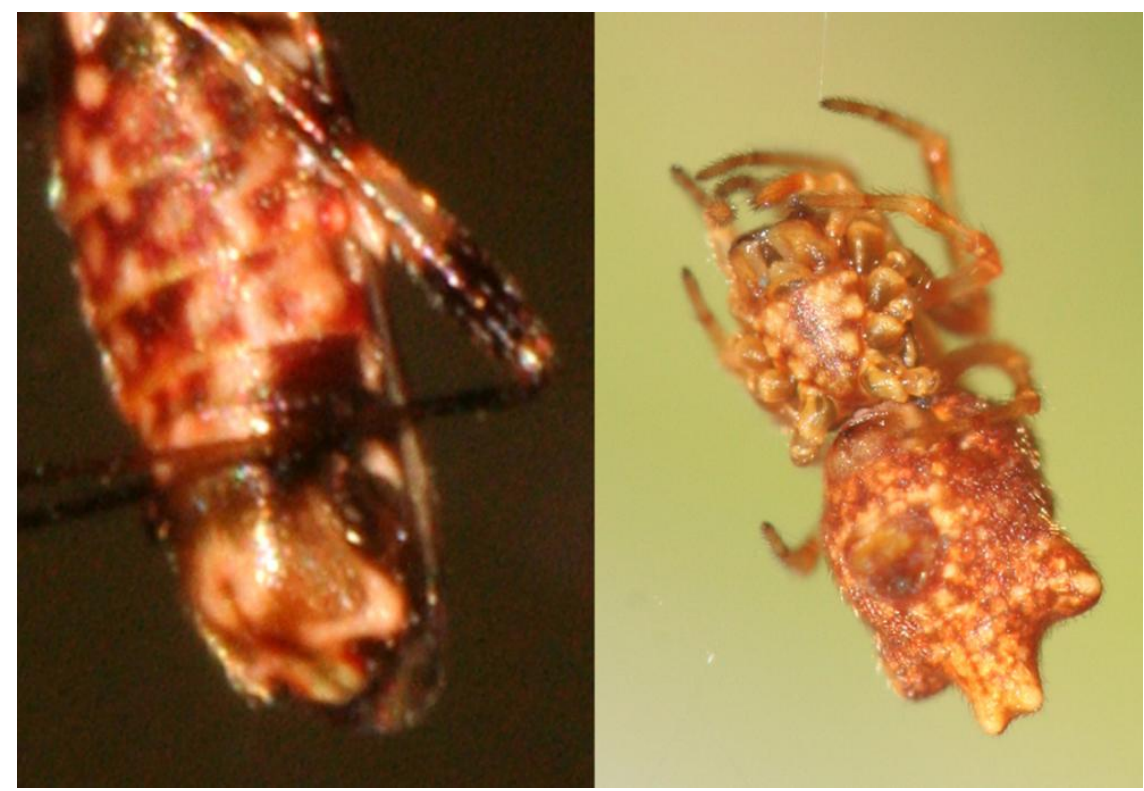

Figure 7. Wicklerian-Eisnerian mimicry of an adult male Arachnocoris berytoides (left) of its host-commensal spider model Faiditus caudatus (Taczanowski) (right). Photos by J. E. Mercado.

\section{Other suggested types of mimicry}

In addition to deceiving its host spider, mimicry in A. berytoides could have other functions. For instance, when seen from above, the ventral testaceous and yellow spots appear to be arranged in a pattern resembling certain wasps (Figure 8). The wasp's abdominal petiole might be simulated by black markings surrounding the brightly colored areas, aided by the habitats' dark background. Is possible that these markings help drive off flying spider-web thieves; therefore, working as Batesian or Mullerian mimicry, since the insect's palatability is unknown (Wappler 2011). 


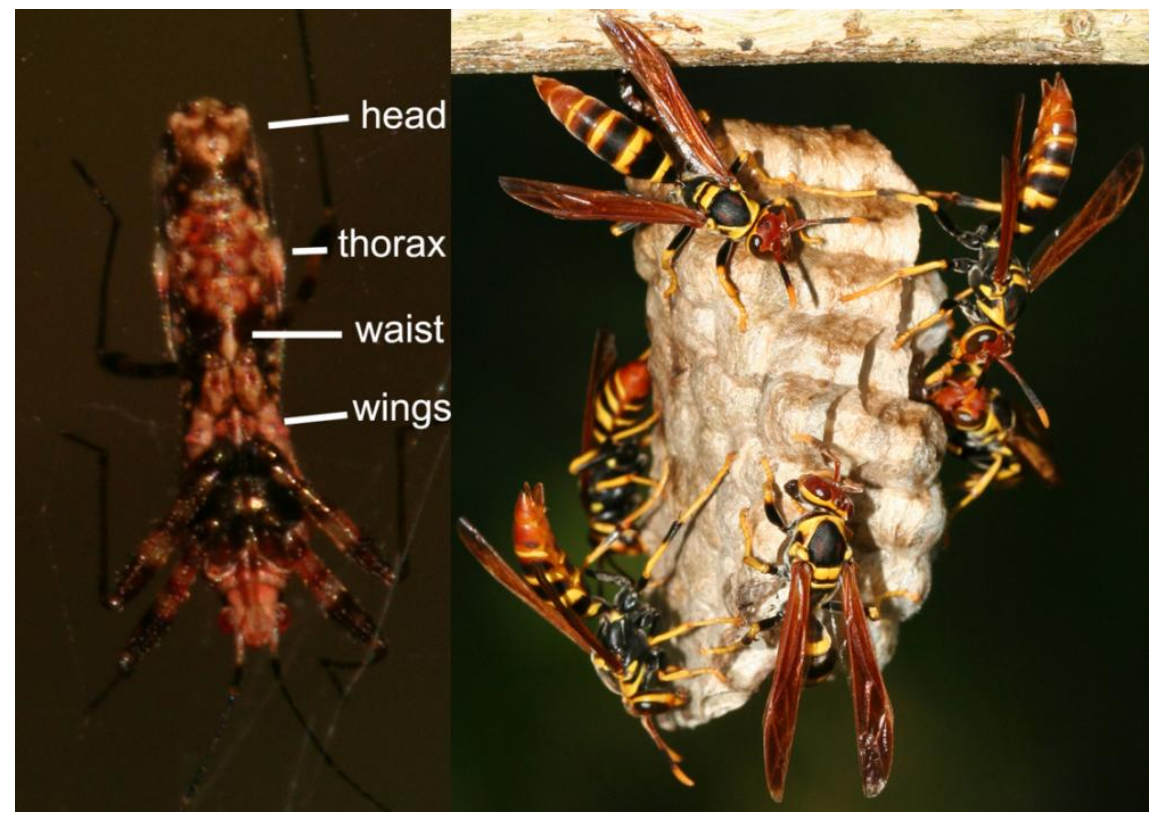

Figure 8. The ventral coloration of Arachnocoris berytoides resembles an aposematic wasp, an example of Mullerian-Batesian mimicry, Polistes crinitus Fenton from Puerto Rico as possible model. Photos by J. E. Mercado.

The habit of living in the precarious environment represented by a spider web may have possibly served as a top-down selective pressure for the development of mimicry in this species providing multiple models to imitate. Therefore, the variation in coloration and morphology of the different life stages of $A$. berytoides has possibly evolved into a multiple-model mimicry system. In which these different types of mimicry work together to provide protection to the tiny insect against the risks of its habitat.

\section{Acknowledgements}

This manuscript was benefited by the invaluable comments of Drs. Boris C. Kondratieff and Paul Ode, as well as four anonymous reviewers. I (author JEM) would like to specially thank the kindness of Mr. Alfredo D. Colón-Archilla, a friend and an extraordinary photographer who kindly provided the photo of the feeding Emesa terrenima. The Rocky Mountain Research Station provided the microphotography equipment.

\section{Literature Cited}

Bergroth, E. 1914. Note on the genus Arachnocoris Scott. The Entomologist's Monthly Magazine Second Series 25(293):116-117.

Bradoo, B. L. and K. J. Joseph. 1970. Life history and habits of Oligotoma greeniana Enderlein (Oligotomidae: Embioptera) commensal in the nest of social spider Stegodyphus sarasinorum Karsch. Indian Journal of Entomology 32:16-21. 
Coscarón, M. D. C., and L. N. Volpi. 2013. Nomenclatural and bibliographic corrections to the Catalog of Nabidae (Hemiptera: Heteroptera) for the Neotropical Region. Zootaxa 3646(1):093-096. http://dx.doi.org/10.11646/zootaxa.3646.1.9

Dalsgaard, B., A. M. M. González, J. J. Olesen, J. Ollerton, A. Timmermann, L. H. Andersen, and A. G. Tossas. 2009. Plant-hummingbird interactions in the West Indies: floral specialization gradients associated with environment and hummingbird size. Oecologia 159(4):757-766. http://dx.doi.org/10.1007/s00442-008-1255-z

Henry, T. J. 1984. Revision of the spider-commensal plant bug genus Ranzovius Distant (Heteroptera: Miridae). Proceedings of the Entomological Society of Washington 86(1):53-67.

Huber, B. A., N. Fischer, and J. J. Astrin. 2010. High level of endemism in Haiti's last remaining forests: a revision of Modisimus (Araneae: Pholcidae) on Hispaniola, using morphology and molecules. Zoological Journal of the Linnean Society 158:244-299. http://dx.doi.org/10.1111/j.1096-3642.2009.00559.x

Kerzhner, I. M. 1990. Neotropical Nabidae (Heteroptera), 3: Species of the genus Arachnocoris from Costa Rica. Journal of New York Entomological Society 98(2):133-138.

Lopez-Moncet, A. 1990. Arachnocoris karukerae n. sp. (Hemiptères: Hétéroptères), nabide commensal de Pholcidae (Araignées) aux Antilles Françaises. Bulletin de la Société Sciences Naturales 65:3-7.

Lopez-Moncet, A. 1997. Observations systématiques et biologiques sur le genre Arachnocoris Scott 1881 (Hétérocères: Nabidae) Deuxième note. Lambillionea 1(4):528-538.

McIver, J. D. and G. Stonedahl. 1993. Myrmecomorphy: Morphological and behavioral mimicry of ants. Annual Review of Entomology 38:351-379. http://dx.doi.org/10.1146/annurev.en.38.010193.002031

Murphy, D. H. and D. A. Polhemus. 2012. A new genus of micropterous Miridae from Singapore mangroves (Insecta: Hemiptera: Heteroptera). The Raffles Bulletin of Zoology 60(1):109-115

Myers, J. G. 1925. Biological notes on Arachnocoris albomaculatus Scott (Hemiptera; Nabidae). Journal of New York Entomological Society 33, 136-146.

Nafus, D. and I. Schriener. 1991. Oviposition by herbivorous insects on spider webs as an antipredator defense. Ecological Entomology 16:513-517. http://dx.doi.org/10.1111/j.13652311.1991.tb00244.x

Parker, G. A. 1974. Courtship persistence and female-guarding as male time investment strategies. Behaviour 48(1):157-183. http://dx.doi.org/10.1163/156853974X00327

Pasteur, G. 1982. A classificatory review of mimicry systems. Annual Review of Ecology and Systematics 13:169-199. http://dx.doi.org/10.1146/annurev.es.13.110182.001125

Popov, Y. A. 2008. Pavlostysia wunderlichi gen. nov. and sp. nov., the first fossil spider-web bug (Hemiptera: Heteroptera: Cimicomorpha: Plokiophilidae) from the Baltic Eocene amber. Acta Entomologica Musei Nationalis Pragae 48(2):497-502.

Santiago-Blay, J. A. and J. Maldonado-Capriles. 1988. Observations on the true bugs Emesa tenerrima, a possible spider mimic, and Ghilianella borincana (Hemiptera: Reduviidae: Emesinae) from Puerto Rico. Proceedings of the Entomological Society of Washington. 90: 369-372.

Scott, J. 1881. Description of a new genus and two species of Hemiptera-Heteroptera from South America. The Entomologist's Monthly Magazine 17:272-274.

Sewlal, J. N. and C. K. Starr. 2008. Observations of the insect Arachnocoris trinitatus (Heteroptera: Nabidae) as an inquiline in the webs of the spider Mesabolivar aurantiacus (Araneae: Pholcidae). Caribbean Journal of Science 44(1):132-135.

Sewlal, J. N. and C. K. Starr. 2009. Observations of the insect Arachnocoris trinitatus (Heteroptera: Nabidae) as an inquiline of the spider Coryssocnemis simla (Araneae: Pholcidae) in West Indies. Zoosystematica Rossica 18(1):59-61.

Soley, F. G., R. R. Jackson, and P. W. Taylor. 2011. Biology of Stenolemus giraffa (Hemiptera: Reduviidae), a web invading, araneophagic assassin bug from Australia. New Zealand Journal of Zoology 38(4):297-316. http://dx.doi.org/10.1080/03014223.2011.604092 
Weinmann, D. and R. H. L. Disney. 1997. Two new species of Phoridae (Diptera) whose larvae associate with large spiders (Araneae: Theraphosidae). Journal of Zoology 243(2):319-328. DOI: $10.1111 /$ j.1469-7998.1997.tb02785.x 